\title{
Pontic site development with an implant submergence technique for unaesthetic implant in the anterior maxilla
}

\author{
Yujeong Song', Ju-Youn Lee ${ }^{2 *}$ \\ 'Department of Periodontology, Pusan National University Dental Hospital, Yangsan, Republic of Korea \\ ${ }^{2}$ Department of Periodontology, School of Dentistry, Pusan National University, Yangsan, Republic of Korea
}

Improving implant esthetics is very difficult, especially in cases where unaesthetic problems are related to implants in the maxillary anterior dentition. A 69-year old male patient was referred by a prosthodontist for periodic pus discharge and an unaesthetic implant prosthesis (maxillary right lateral incisor). The implant was placed too deeply and showed soft tissue volume deficiency and a long clinical crown. After a clinical and radiographic examination, implant submergence and alveolar ridge augmentation were performed to enhance the aesthetics instead of an explantation. The treatment plan was as follows: extraction the adjacent teeth with tooth mobility, secondary caries, and poor prognosis; placement an additional dental implant with hard and soft tissue grafting; fabrication a fixed bridge using implant abutments. A fixed esthetic prosthesis using implants was fabricated, and the patient was satisfied with the prosthesis. A ridge augmentation with implant submergence may be an alternative for solving the problems of unaesthetic implant restorations in the esthetic zone. (J Dent Rehabil Appl Sci 2020;36(4):289-95)

Key words: dental implants; dental esthetics; ridge augmentation; maxillae

\section{Introduction}

Despite the high long term success rate of implant prostheses, implant restorations in the anterior dentition could cause some trouble concerning esthetics. Esthetic complications in implant therapy represent a clinical challenge when the aim is to overcome the sequelae and obtain a pleasing result. ${ }^{1}$ In particular, it is very difficult to correct unaesthetic problems in malpositioned implants and single implant cases because the implant integrates imperceptibly with the surrounding hard and soft tissues. ${ }^{1,2}$

Esthetic complications related to implant therapy can be characterized into several categories according to their origin. ${ }^{1,2}$ Most clinicians agree with the opin-

*Correspondence to: Ju-Youn Lee

Professor, Department of Periodontology, School of Dentistry, Pusan National University,

20 Geumo-ro, Beomeo-ri, Mulgeum-eup, Yangsan, 50612, Republic of Korea

Tel: +82-55-360-5202, Fax: +82-55-360-5194, E-mail: heroine@pusan.ac.kr

Received: September 29, 2020/Last Revision: November 2, 2020/Accepted:

November 2, 2020 ion that 3-D positioning is very important in acquiring esthetics, and iatrogenic malpositioned implants are the most challenging cases. ${ }^{1}$ An unaesthetic implant resulting from an excessive depth of placement is challenged by the long-term continued facial tissue resorption to the point of biological stability. This causes soft tissue problems, such as recession, papillae deficiency, and insufficient volume.

Mesquita De Carvalho et al. ${ }^{1}$ proposed a clinical decision tree of the therapeutic alternatives of unaesthetic implant problems based on the implant position and the deficiency of hard and soft tissue: reconstruction of hard tissue and/or soft tissue, implant submergence, orthodontic forced eruption of adjacent teeth, and explantation. In the case of

CopyrightC 2020 The Korean Academy of Stomatognathic Function and Occlusion. (c) It is identical to Creative Commons Non-Commercial License. 
malpositioned implants, they proposed that explantation as the first choice of treatment. ${ }^{1}$ On the other hand, the removal of esthetically failed implants can cause serious alveolar ridge defects because explantation is an aggressive process. The unfortunate decision to remove an esthetically failed implant requires extreme caution and an estimation of the resulting tissue deficiency. Hard and soft tissue augmentation before, during, or after implant placement have been widely used. ${ }^{3,4}$ The root submergence technique is intended to prevent bone resorption at the pontic site. ${ }^{5}$

In this report, the patient had an esthetically failed and inflamed implant that had been placed too deeply in the maxillary anterior dentition. The alternative, a ridge augmentation with an implant submergence, was adopted considering the advantages and disadvantages of the several options available. This study proposes a ridge augmentation with an implant submergence as a therapeutic alternatives of nonesthetic implant prosthetics in the anterior dentition.

\section{Case Report}

A 69-year-old man visited the Department of Periodontology at Dental Hospital. His chief complaints were periodic pus discharge and non-esthetic implant prosthesis of the maxillary lateral incisor (tooth 12[FDI tooth numbering system]). The patient had no remarkable systemic disease affecting the dental condition.

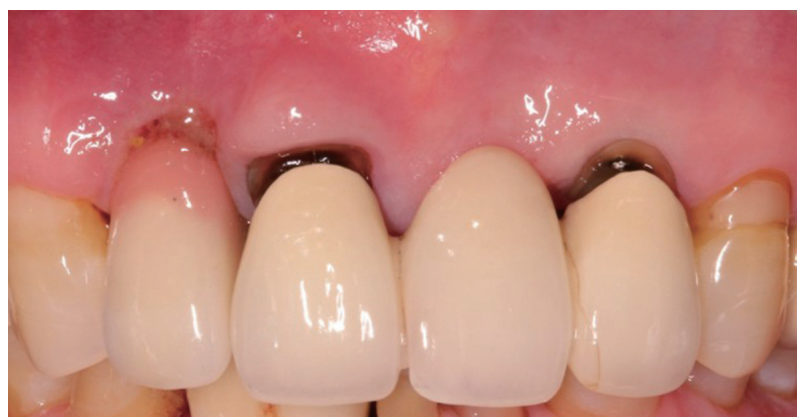

Fig. 1. Initial clinical presentation. Note the long clinical crown with pink ceramic and pus discharge around the maxillary right lateral incisor (\#12 dental implant). The marginal soft-tissue interface around the cervical portion of the implant had a recession and lack of ridge volume. Maxillary right central incisor and left lateral incisor had poor esthetics and deep secondary caries.
An implant-supported single prosthesis was fabricated 1 year ago, of which the fixture was placed by immediate implantation in a local dental clinic. Gingival bleeding, purulent exudates, deep probing depth (distobuccal, midbuccal, mesiobuccal, palatal, $7,10,10$, and $5 \mathrm{~mm}$ ), and a long clinical crown with pink porcelain were present around the implant (Fig 1). The adjacent maxillary anterior 3 unit fixed bridge \{right central incisor (\#11) left lateral incisor (\#22)\} had mobility degree II, short root length, and deep secondary caries with a hopeless prognosis (Fig $2 \mathrm{~A}$ and $2 \mathrm{C}$ ). A radiographic examination including cone-beam computed tomography (CBCT) disclosed that the \#12 implant had been placed reasonably in $3 \mathrm{D}$ positioning except apico-coronal deep positioning, and there was mild marginal bone resorption around the fixture (Fig. 2B). Furthermore, the neighboring alveolar bone shape and volume were appropriate for implantation at \#11 and \#22.

Therefore, the periodontist and prosthodontist agreed that the esthetics of the deep positioned single implant (\#12) could not be improved, and mobile three-unit prosthesis should be removed. Instead of
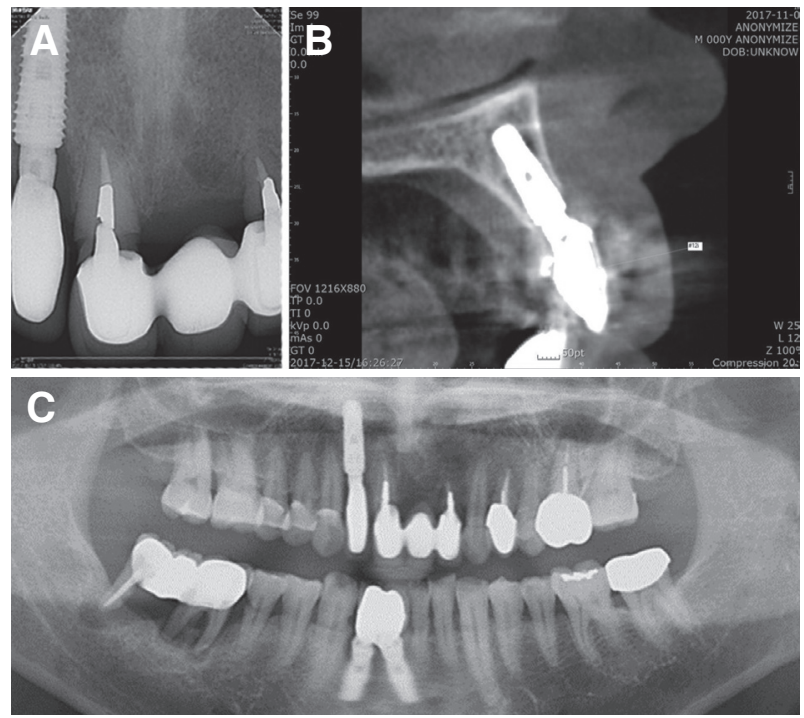

Fig. 2. Initial periapical view (A), Cone beam computed tomography $(\mathrm{B})$ and panoramic view $(\mathrm{C})$. The preexisting implant fixture was placed reasonably in the mesiodistal and buccolingual direction. Note the deep positioning of the implant in the apico-coronal direction, mild marginal bone loss, and too wide fixture relative to the buccal bone thickness. 
surgical removal of the \#12 implant, the alternative, submerging the fixture of \#12, placing two implants at \#11 and \# 22, and fabrication of four-unit fixed bridge with a cantilever bridge (\#12), was proposed to the patient.

The treatment planning was as follows: anti-infective therapy of inflammation of the \#12 implant, extraction of \#11 and \#22, implantation of \#11 and \#22 (early approach) with guided bone regeneration (GBR), and submerging of the \#12 implant with GBR and soft tissue augmentation.

The following methods were adopted to resolve the inflammation around the \#12 implant; mechanical cleansing using titanium curettes, improvement of the patient's oral hygiene, and pocket irrigation with
$0.12 \%$ chlorhexidine digluconate solution (CHX; Hexamedine $^{\circledR}$, Bukwang pharm, Seoul, Korea) after removing the implant prosthesis. Despite the antiinfective therapy of the \#12 implant, soft tissue deficiency was noticeable (Fig. 4A). The teeth \#11 and \#22 were extracted using periotomes to preserve the surrounding alveolar bone, particularly, the buccal bony plate.

Two months later, for soft tissue maturation, all the surgical procedures planned were performed (Fig. 3A-C). After appropriate local anesthesia and flap elevation, the granulation tissues over the implant surface and the bony defect were removed carefully using a titanium curette (Osung MND, Seoul, Korea). The implant surfaces were cleaned carefully with cot-

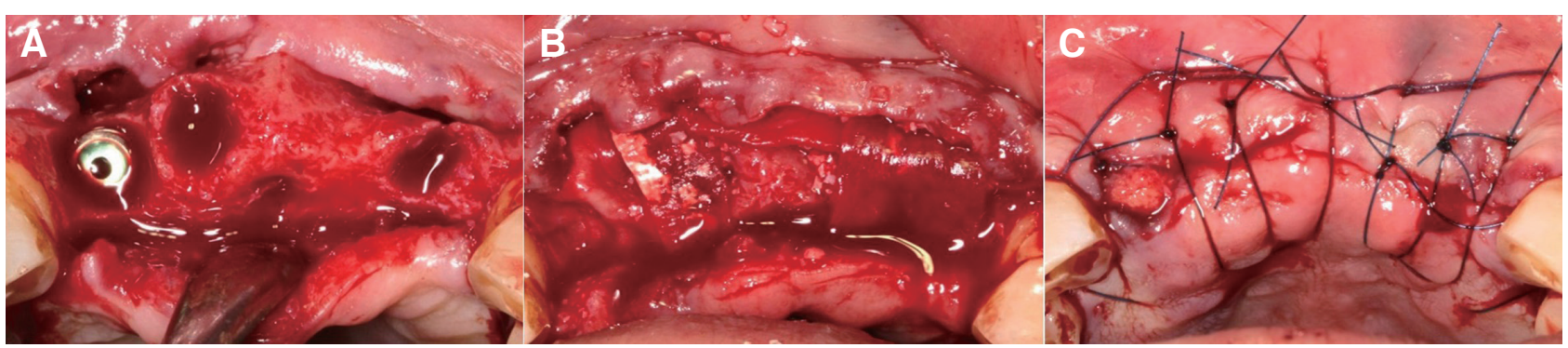

Fig. 3. Clinical presentation at each steps of the surgical phase of treatment. Two months after the extraction of the hopeless teeth (\#11 and \#22). Note shallow circular intrabony defect at implant site 12 (A). After implantation of \#11 and \#22, the defect around \# 12 and buccal defect over \#11 and \#22 were augmented with bovine bone minerals (BioOss, Geistlich) and non-cross linked bioresorbable membrane (Bio-Gide, Geistlich) (B). Suturing after palatal pedicle graft at implant site $12(\mathrm{C})$.

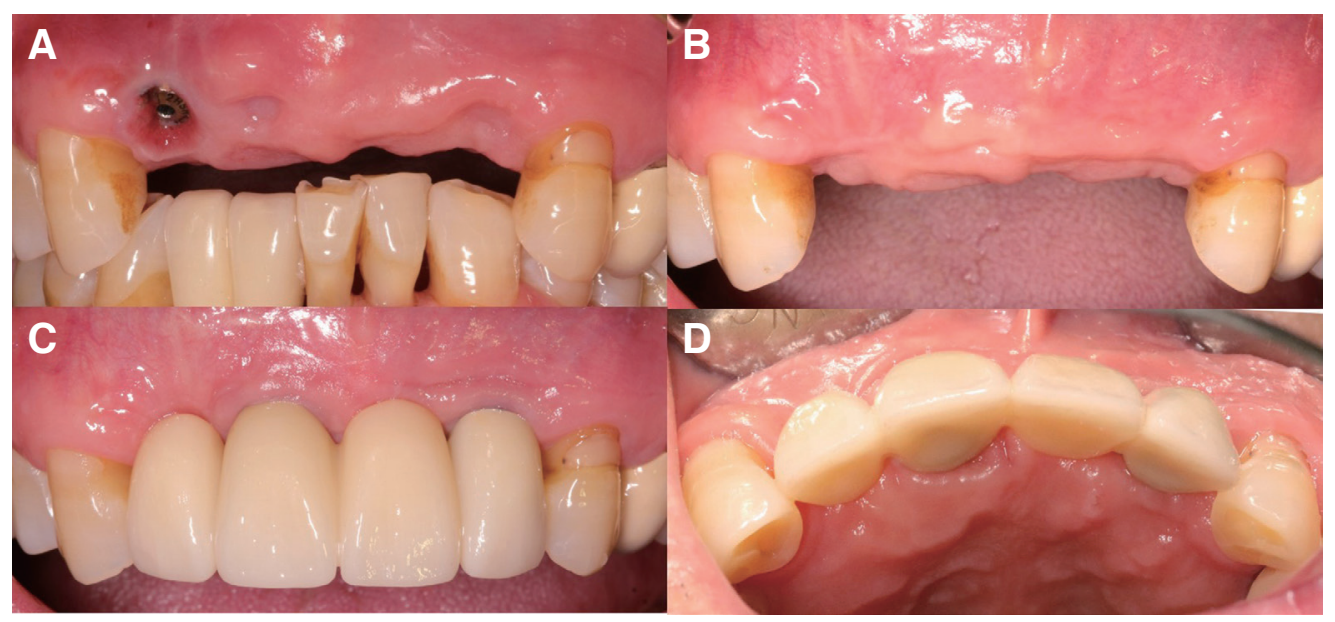

Fig. 4. Preoperative clinical situation (A). Note the unaesthetic gingival margin and the deficiency of buccal ridge volume of the maxillary right lateral incisor after removing the implant prosthesis. After the surgical procedure, the ridge volume was restored and the gingival margin was corrected (B). Final restoration after implant surgery with ridge augmentation and implant submergence ( $C$ and $D$ ). Gingival volume was restored, and gingival level coincided with the neighboring dentition. 
ton pellets soaked sequentially in $0.12 \% \mathrm{CHX}$ and normal saline for detoxification of the implant surfaces and the 2-staged implant surgery of the other two implants (TS IIISA, Osstem, Seoul, Korea) were performed. All bony defects were augmented with a bovine bone mineral (Bio-Oss, Geistlich, Wolhusen, Swiss) and non-cross linked bioresorbable membrane (Bio-Gide, Geistlich). A palatal pedicle graft was performed simultaneously to compensate for the vertical and horizontal soft tissue deficiency of the \#12 implant. The patient was administered systemic antibiotics (amoxicillin $250 \mathrm{mg}$ and metronidazole $250 \mathrm{mg}$ three times a day) for one week. The patient was instructed to avoid mechanical cleaning in the surgical area and rinse with $0.12 \% \mathrm{CHX}$ solution twice a day for 14 days. All the sutures were removed at 2 weeks after surgery and healing was uneventful. The ridge volume was restored successfully (Fig. 4B). The second surgery of the implants was performed 4 months later, and a fixed provisional restoration was fabricated. After 6-month healing period, the final fixed prosthetic reconstructions were placed (Fig. 4C-D and 5). The final prosthesis was in harmony

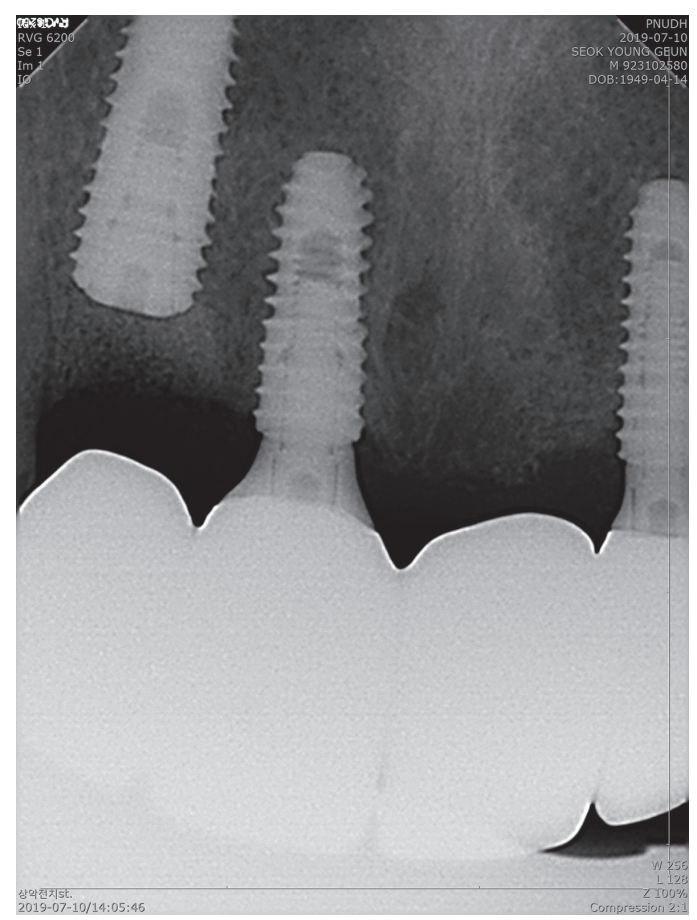

Fig. 5. Periapical view after completion of the final restoration. Deep positioning of the existing implant (\#12) was remarkable. with the adjacent teeth and the augmented ridge volume. The gingival tissue around the restoration and the submerged implant was healthy and esthetic.

\section{Discussion}

New parameters to assess the success of dental implant include health status and natural-looking periimplant soft tissue. ${ }^{6}$ Despite the variety of surgical techniques for the soft and hard tissue augmentation for the correction of unaesthetic implant prostheses, many esthetic problems of an implant cannot be corrected fully. ${ }^{7}$ The etiology of peri-implant mucosal recessions may be related to various factors, such as the gingival phenotype, ${ }^{8}$ the width of attached gingiva, the height and thickness of the buccal bone wall, ${ }^{9}$ and orofacial malposition of the implant. ${ }^{10}$

Three-dimensional implant positioning is the most important factor determining the future treatment of the esthetic problem, and preserving the width of the interproximal bone is crucial for the preserving the interdental papillae. Regarding the vertical position, the neck of the implant must be located in the correct apico-coronal positioning, which will generally fall within 2 - $4 \mathrm{~mm}$ apical to the future-or desiredmucosal margin. ${ }^{11}$ Recession of the facial mucosal margin was a common observation in several studies with immediate implant placement. The risk for mucosal recession increases dramatically through the combination of immediate implant placement, flapless surgeries, and limited clinical experience. ${ }^{12}$ Therefore, in this case, deep positioning with immediate implantation might accelerate the recession, deep pocket, and inflammation of the implant (\#12).

At the first clinical examination, lack of soft tissue volume, recession, pus discharge, and deep probing depth were observed at implant site 12. Suppuration and deep pocket are associated with disease activity and indicate a need for anti-infective therapy. Therefore, anti-infective therapy before surgery based on a well-established protocol, the cumulative interceptive supportive therapy of peri-implantitis was performed. ${ }^{13}$

Most dentists agree to remove iatrogenic malpositioned implants to improve of esthetics. On the 
other hand, the removal of implant is an aggressive procedure that inevitably causes the loss of healthy supporting bone. To overcome these problems, an appropriate treatment planning, including a thorough clinical examination (visual analysis, peri-implant probing and so on), radiographic assessment, and cast analysis, is necessary.

Imaging technologies are an important diagnostic tool. Periapical radiography identifies the size and type of an implant and the presence/absence of the interproximal bone crest. CBCT may help assess the condition of the surrounding bone and the volume of soft tissue around the implant. ${ }^{14}$ The facial bone may not be visible, particularly when its thickness is below $1 \mathrm{~mm} .{ }^{15}$ In this case, the buccal bone was identified during surgery, despite the buccal crest not being observed clearly on the CBCT image. Dentists should be familiar with these points for accurate treatment planning. Therefore, bone augmentation only in the circular intrabony defect of implant site 12 and soft tissue augmentation were performed to increase the ridge volume.

Many studies have suggested various implant surface decontamination methods; air-abrasive instrument with glycine, ${ }^{16}$ irradiation with and Er:YAG laser, ${ }^{17}$ washing with $0.12 \% \mathrm{CHX}$ and saline ${ }^{18}$ and so on. Because no method is superior, simple and effective methods were adopted, i.e., washing with $0.12 \%$ CHX and normal saline and cleaning with cotton pellets soaked in normal saline and $0.12 \%$ CHX.

Flap management is considered more important than the grafting technique itself. Several surgical techniques have been developed to achieve the primary closure of bone augmentation sites, including coronally advanced flap, connective tissue grafts, and palatal split pedicle flap. ${ }^{12}$ The palatal pedicle graft technique was chosen for soft tissue volume augmentation because sufficient subepithelial connective tissue was present in the surgical site, which has the advantage of a profound double blood supply and less patient morbidity. As a result, the healing was rapid and uneventful.

Dental practitioners could consider that esthetically failed implant fixtures do not always have to be removed at the expense of the supporting structure to improve esthetics. Just as a root submergence for preventing ridge collapse, ${ }^{19}$ an implant surrounded by healthy periodontium can be submerged for ridge maintenance or augmentation. Mild peri-implant inflammation could be well controlled by anti-infective therapy, ${ }^{13}$ and implant submergence with soft and hard tissue augmentations could be an alternative to non- esthetic implant fixed prosthesis that can simplify difficult treatment planning.

\section{Conclusion}

For an unaesthetic implant surrounded by healthy periodontium, an implant submergence with or without soft and hard tissue augmentation could be considered for an another treatment option.

\section{Acknowledgements}

This work was supported by a 2-year Research Grant of Pusan National University.

\section{ORCID}

Yujeong Song https://orcid.org/0000-0002-7458-6839

Ju-Youn Lee https://orcid.org/0000-0002-0772-033X

\section{References}

1. Mesquita de Carvalho PF, Joly JC, Carvalho da Silva R, González-Martín O. Therapeutic alternatives for addressing pink esthetic complications in singletooth implants: A proposal for a clinical decision tree. J Esthet Restor Dent 2019;31:403-14.

2. Cooper LF, De Kok IJ, Thalji G, Bryington MS. Prosthodontic Management of Implant Therapy: Esthetic Complications. Dent Clin North Am 2019; 63:199-216.

3. Buser D, Dula K, Belser UC, Hirt HP, Berthold H. Localized ridge augmentation using guided bone regeneration. II. Surgical procedure in the mandible. Int J Periodontics Restorative Dent 1995;15:10-29.

4. Grunder U. Crestal Ridge Width Changes When Placing Implants at the Time of Tooth Extraction With and Without Soft Tissue Augmentation After 
a Healing Period of 6 Months: Report of 24 Consecutive Cases. Int J Periodontics Rest 2011;31:917.

5. Comut A, Mehra M, Saito H. Pontic site development with a root submergence technique for a screw-retained prosthesis in the anterior maxilla. J Prosthet Dent 2013;110:337-43.

6. Papaspyridakos P, Chen CJ, Singh M, Weber HP, Gallucci GO. Success criteria in implant dentistry: a systematic review. J Dent Res 2012;91:242-8.

7. Joo JY, Son S, Lee JY. Implant Site Development for Enhancing Esthetics of Soft and Hard Tissue and Simplification of Implant Surgery Using a Forced Eruption. Int J Periodontics Restorative Dent 2016;36:583-9.

8. Kan JY, Rungcharassaeng K, Lozada JL, Zimmerman G. Facial gingival tissue stability following immediate placement and provisionalization of maxillary anterior single implants: a 2- to 8-year followup. Int J Oral Maxillofac Implants 2011;26:179-87.

9. Buser D, Martin W, Belser UC. Optimizing esthetics for implant restorations in the anterior maxilla: anatomic and surgical considerations. Int J Oral Maxillofac Implants 2004;19 Suppl:43-61.

10. Evans CD, Chen ST. Esthetic outcomes of immediate implant placements. Clin Oral Implants Res 2008;19:73-80.

11. Funato A, Salama MA, Ishikawa T, Garber DA, Salama H. Timing, positioning, and sequential staging in esthetic implant therapy: a four-dimensional perspective. Int J Periodontics Restorative Dent 2007;27:313-23.

12. Chackartchi T, Romanos GE, Sculean A. Soft tissue-related complications and management around dental implants. Periodontol 2000 2019;81:124-38.

13. Mombelli A, Lang NP. The diagnosis and treatment of peri-implantitis. Periodontol 2000 1998;17:6376.

14. Januário AL, Barriviera M, Duarte WR. Soft tissue cone-beam computed tomography: a novel method for the measurement of gingival tissue and the dimensions of the dentogingival unit. J Esthet Restor Dent 2008;20:366-73.

15. González-Martín O, Oteo C, Ortega R, Alandez J, Sanz M, Veltri M. Evaluation of peri-implant buc- cal bone by computed tomography: an experimental study. Clin Oral Implants Res 2016;27:950-5.

16. Singh G, O’Neal RB, Brennan WA, Strong SL, Horner JA, Van Dyke TE. Surgical treatment of induced peri-implantitis in the micro pig: clinical and histological analysis. J Periodontol 1993;64:984-9.

17. Kreisler M, Kohnen W, Christoffers AB, Götz H, Jansen B, Duschner H, d'Hoedt B. In vitro evaluation of the biocompatibility of contaminated implant surfaces treated with an Er: YAG laser and an air powder system. Clin Oral Implants Res 2005; 16:36-43.

18. Wetzel AC, Vlassis J, Caffesse RG, Hämmerle CH, Lang NP. Attempts to obtain re-osseointegration following experimental peri-implantitis in dogs. Clin Oral Implants Res 1999;10:111-9.

19. Salama M, Ishikawa T, Salama H, Funato A, Garber D. Advantages of the root submergence technique for pontic site development in esthetic implant therapy. Int J Periodontics Restorative Dent 2007;27:521-7. 


\section{상악 전치부 임플란트의 비심미성 개선을 위한 임플란트 침수(submergence)를 동반한 치조제 증대술}

송유정 ${ }^{1}$ 전공의, 이주연 ${ }^{2 *}$ 교수

${ }^{1}$ 부산대학교치과병원 치주과

${ }^{2}$ 부산대학교 치의학전문대학원 치주과학교실

비심미적인 임플란트유지형 보철물의 심미성 개선은 매우 어려운 문제이며 특히, 상악 전치부 임플란트와 관련되어 있는 경우는 더욱 그러하다. 본 증례는 상악전치부 임플란트의 주기적 배농과 비심미성을 주소로 보철과의사로부터 의뢰된 69세 남자 환자의 심미성 개선에 관한 보고이다. 임플란트는 다소 깊게 식립되어 긴 임상치관길이를 보였으며, 주변 연조 직 양도 부족하였다. 임상 검사와 방사선검사 후, 깊게 식립된 임플란트의 제거 대신 예후가 불량한 인접 치아의 발치 후 임플란트를 추가 식립하여 임플란트 유지형 고정성보철물을 제작하고, 깊게 식립된 임플란트는 제거 대신 치조제 증대 에 도움을 주기 위해 침수(submergence)시켜 치조제를 증대시키는 방식을 선택하였다. 적절한 진단이 동반된 임플란트 침수가 전치부의 임플란트 비심미성을 개선시킬 수 있는 또다른 대안이 될 수 있을 것이다.

(구강회복응용과학지 2020;36(4):289-95)

주요어: 치과임플란트; 치과심미성; 치조제증대술; 상악골

*교신저자: 이주연

(50612)경상남도 양산시 물금읍 금오로 20 부산대학교 치의학전문대학원 치주과학교실

Tel: 055-360-5202 | Fax: 055-360-5194 || E-mail: heroine@pusan.ac. kr

접수일: 2020년 9월 29일 | 수정일: 2020년 11월 2일 | 채택일: 2020년 11월 2일 